Pesq. Vet. Bras. 29(11):874-880, novembro 2009

\title{
Hematological and immunological responses of Nile tilapia after polyvalent vaccine administration by different routes ${ }^{1}$
}

Bruno C. Silva ${ }^{2,3 *}$, Mauricio L. Martins ${ }^{3}$, Adolfo Jatobá ${ }^{2}$, Celso C. Buglione Neto $^{2}$, Felipe N. Vieira ${ }^{2}$, Gabriella V. Pereira² ${ }^{2}$, Gabriela T. Jerônimo ${ }^{3}$, Walter Q. Seiffert ${ }^{2}$ and José Luiz P. Mouriño2,3

\begin{abstract}
Silva B.C., Martins M.L., Jatobá A., Buglione Neto C.C., Vieira F.N., Pereira G.V., Jerônimo G.T., Seiffert W.Q. \& Mouriño J.L.P. 2009. Hematological and immunological responses of Nile tilapia after polyvalent vaccine administration by different routes. Pesquisa Veterinária Brasileira 29(11):874-880. Laboratório de Diagnóstico e Patologia em Aqüicultura, Departamento de Aqüicultura, Centro de Ciências Agrárias, Universidade Federal de Santa Catarina, Rodovia Ademar Gonzaga 1346, Itacorubi, Florianópolis, SC 88034-001, Brazil. E-mail: bcs85@ hotmail.com

The efficacy of a polyvalent bacterin vaccine against Aeromonas hydrophila, Pseudomonas aeroginosa and Enterococcus durans administered by different routes in Nile tilapia was assessed by analyzing hematological and immunological parameters 7 and 21 days after vaccination. Treatments consisted of: non-vaccinated tilapia; tilapia vaccinated by intraperitoneal injection with $2 \times 10^{8}$ formalin-inactivated bacteria $\cdot \mathrm{mL}^{-1}$; tilapia vaccinated orally with $2 \times 10^{7}$ formalin-inactivated bacteria. $g^{-1}$, feed for 5 days; tilapia vaccinated by immersion bath in $2 \times 10^{7}$ formalin-inactivated bacteria $\mathrm{mL}^{-1}$, for 20 minutes. Vaccinated fish groups presented higher hematocrit, number of erythrocytes and leukocytes than the non-vaccinated group. Serum agglutination titer of intraperitoneally vaccinated fish was higher on both evaluation periods for the three bacteria strains. Only on day 21 post-vaccination fish from the oral and immersion vaccination groups presented higher serum agglutination titer than the non-vaccinated fish for $A$. hidrophyla and $E$. durans. Serum antimicrobial activity in vaccinated fish was higher for $P$. aeroginosa and $E$. coli than in non-vaccinated fish on both evaluation periods. The different vaccine administration routes stimulated hematological and immunological responses in Nile tilapia 21 days post-vaccination, but intraperitoneal vaccination presented higher total number of leukocytes, lymphocytes and serum agglutination titer.
\end{abstract}

INDEX TERMS: Oreochromis niloticus, vaccine, hematology, immunology.

RESUMO.- [Resposta hematológica e imunológica de tilápia do Nilo após administração de vacina polivalente por diferentes vias.] Este estudo avaliou a eficácia da administração de vacina polivalente (bacterina), con-

\footnotetext{
${ }^{1}$ Received on February 17, 2007.

Accepted for publication on June 8, 2009.

2 Setor de Microbiologia, Laboratório de Camarões Marinhos, Departamento de Aqüicultura, Centro de Ciências Agrárias (CCA), Universidade Federal de Santa Catarina (UFSC), Rua Beco dos Coroas $s / n$, Barra da Lagoa, Florianópolis, SC 88062-601, Brasil.

3 Laboratório de Diagnóstico e Patologia em Aqüicultura, Departamento de Aqüicultura, CCA-UFSC, Rodovia Ademar Gonzaga 1346, Itacorubi, Florianópolis, Santa Catarina 88034-00. *Corresponding author: bcs85@ hotmail.com
}

tra Aeromonas hydrophila, Pseudomonas aeroginosa e Enterococcus durans, por diferentes vias de aplicação em tilápia do Nilo, analisando parâmetros hematológicos e imunológicos no $7^{\circ}$ e $21^{\circ}$ dia após vacinação. Os tratamentos consistiram de: tilápias não vacinadas; tilápias vacinadas via injeção intraperitoneal (i.p.) contendo $2 \times 10^{8}$ bactérias inativadas $\cdot \mathrm{mL}^{-1}$; tilápias alimentadas com ração contendo vacina na proporção de $2 \times 10^{7}$ bactérias inativadas $\cdot g^{-1}$, durante 5 dias; tilápias vacinadas por banho de imersão em $2 \times 10^{7}$ bactérias inativadas $\mathrm{mL}^{-1}$, durante 20 minutos. Os peixes vacinados apresentaram maior porcentagem de hematócrito, número de eritrócitos e leucócitos durante o período do experimento, em relação aos não vacinados. O título de aglutinação do soro 
dos peixes vacinados intraperitonealmente foi superior nos dois períodos de avaliação para todas as bactérias. Apenas no $21^{\circ}$ dia os peixes vacinados oralmente e por imersão apresentaram título de aglutinação superior aos peixes não vacinados para $A$. hidrophyla e $E$. durans. $O$ soro dos peixes vacinados apresentou maior atividade antimicrobiana para $P$. aeroginosa e $E$. coli, do que os peixes não vacinados, nos dois períodos. As diferentes vias de administração da vacina estimularam a resposta hematológica e imunológica da tilápia do Nilo após 21 dias de vacinadas, sendo que o número total de leucócitos, linfócitos, título aglutinante do soro dos vacinados i.p. foi maior do que os demais.

TERMOS DE INDEXAÇÃO: Oreochromis niloticus, vacina, hematologia, imunologia.

\section{INTRODUCTION}

With the intensification of aquaculture causing stress on cultured fish, infectious and parasitic diseases appear and culminate in higher fish mortality (Vandenberg 2004). The major causes of economic losses in tilapia culture are bacterial diseases, mostly caused by the genera Aeromonas, Pseudomonas, Vibrio, Flavobacterium, Edwardsiella, Streptococcus and Enterococcus. These infectious agents cause external injuries and can even be found in internal organs as liver, intestines, heart, brain and spleen (Plumb 1997, Shoemaker \& Klesius 1997, Cai et al. 2004, Lim \& Webster 2006).

For the successful development of tilapia culture in Brazil, the industry needs strategies to minimize the effects caused by the mentioned bacteria with the most common treatment to control bacterial diseases being the use of antibiotics that can cause the selection of pathogenic strains (Klaenhammer \& Kullen 1999) and environmental pollution (Boyd \& Massaunt 1999). The development of vaccines shows to be a promising alternative (Lim \& Webster 2006) to avoid the mentioned riscs.

Vaccines are prepared using either antigens, derived from pathogenic organisms, or hole bacterial inactivated cells, which stimulate the immune system of the host and enhances resistance to diseases (Tizard 2002). Antigens activate two systems, the non-specific and the specific immune systems, both with cellular and humoral responses. The non-specific humoral response is composed of lysozymes, complement system, interferon, $C$ reactive protein, transferrin and lectin, and the specific response is mainly due to the activation of $B$ lymphocytes and memory cells (Kaattari \& Piganelli 1996, Secombes 1996, Yano 1996).

The efficacy of vaccines in stimulating the fish immune system is related to the routes of administration, with advantages and disadvantages. However, only a few studies have been done assessing the efficacy of vaccination strategies according to the culture conditions (Vandenberg 2004, Santos et al. 2005, Lim \& Webster 2006).

Among the differents administration routes, intraperitoneal injection has shown the best results (Klesius et al.
1999, Ruangpan et al. 1986). However, it is laborious, costly, stressful to the animals, and only administered in fish of high market price, broodstock or ornamental fish (Austin \& Austin 1993).

Results from bath immersion and oral vaccines in fish are contradictory. Some authors reported unsuccessful results (Vandenberg 2003, Santos et al. 2005, Shoemaker et al. 2006a), whereas others reported satisfactory ones. Evans et al. (2004) reported $55 \%$ mortality of juvenile Nile tilapia vaccinated by immersion and infected with Streptococcus agalactiae against $84 \%$ mortality of nonvaccinated fish. According to Shoemaker et al. (2006a), juvenile Nile tilapia vaccinated orally presented between $17.5 \%$ to $31.5 \%$ mortality after a Streptococcus iniae challenge.

As the diversity of potentially pathogenic agents is very high in the tilapia production, vaccination strategies included the research and development of polyvalent vaccines (Cipriano 2001). The advantage of polyvalent vaccine is the protection of fish against a wide variety of Gram-positive and Gram-negative bacteria strains (Nikoskelainen et al. 2007).

The objective of this study was to assess the efficacy of the administration of a polyvalent vaccine (bacterin) against Aeromonas hydrophila, Pseudomonas aeroginosa and Enterococcus durans, by different administration routes (intraperitoneal injection, oral, and immersion bath) in Nile tilapia (Oreochromis niloticus Linnaeus 1758) and the effects on hematological and immunological parameters 7 and 21 days post-vaccination.

\section{MATERIAL AND METHODS}

Aeromonas hydrophila ATCC 7966 strain, Enterococcus durans ATCC 19492 strain, and Pseudomonas aeroginosa ATCC 27853 strain were activated and isolated by streak-plate in Tryptone Soy Agar culture medium (TSA, Difco), incubated at $25^{\circ} \mathrm{C}$ for $48 \mathrm{~h}$ and prepared according to Klesius et al. (2000). The colonies were individually incubated in brain-heart infusion culture medium (BHI, Difco) and incubated at $30^{\circ} \mathrm{C}$ for $24 \mathrm{~h}$.

After confirmation of bacterial growth, seven serial dilutions $(1 / 10)$ of the cultures were carried out and plated in TSA culture medium (Difco) and incubated at $30^{\circ} \mathrm{C}$ for $24 \mathrm{~h}$. After this period, the colonies were counted to estimate the concentration of each bacteria group present in vaccines. Later, these cultures were suspended in $3 \%$ formalin solution and incubated at $30^{\circ} \mathrm{C}$ for $24 \mathrm{~h}$ under continuous agitation for inactivation, and centrifuged at $1800 \mathrm{xg}$ for 30 minutes. The supernatant containing formalin was discarded and the pellet resuspended in $0.65 \%$ sterile saline solution. The inactivation of bacteria was confirmed by plating $0.1 \mathrm{~mL}$ of bacterial suspension in TSA culture medium (Difco) and incubated at $30^{\circ} \mathrm{C}$ for $72 \mathrm{~h}$. With no colony growth, suspensions were used combined in a 1:1:1 (v/v) ratio to compose the polyvalent vaccine.

The treatments consisted of: NV: non-vaccinated tilapia; IP: tilapia vaccinated by intraperitoneal injection $(1.5 \mathrm{~mL}$ of the vaccine suspension containing $2 \times 10^{8}$ formalin-inactivated bacteria $\cdot \mathrm{mL}^{-1}$ ); OR: tilapia fed twice a day vaccine-added feed at a concentration of $2 \times 10^{7}$ formalin-inactivated bacteria $\mathrm{g}^{-1}$ for 5 days; IM: tilapia bath immersion vaccination with solution 
containing $2 \times 10^{7}$ formalin-inactivated bacteria $\cdot \mathrm{mL}^{-1}$, for 20 minutes. IP and IM treatments were done on day 5 of the OR treatment. Evaluations were done on days 7 and 21 postvaccination (Evans et al. 2004, Esteve-Gassent et al. 2004, Shoemaker et al. 2006a).

Tilapia used in this study were mean weight $267.8 \pm 25.0 \mathrm{~g}$, 72 tilapias were divided into twelve tanks (300L) with aeration, biological filter and heaters. Treatments were done in triplicate in a completely random experimental design. During the experiment period fish were fed twice a day, water temperature was at $30.86 \pm 1.04^{\circ} \mathrm{C}$, dissolved oxygen $4.54 \pm 0.64 \mathrm{mg} \cdot \mathrm{L}^{-1}$ and $\mathrm{pH} 7.30 \pm 0.23$.

After anesthetized with eugenol (1mL:10L), blood was collected from the caudal vein of 3 tilapia per experimental unit using a 3-mL (21G) syringe with 10\% EDTA and a syringe without anticoagulant (approved by the Ethics Commission for the Use of Animals no 23080.024659/2007-99 CEUA/UFSC). Blood collected without anticoagulant was left to clot for $2 \mathrm{~h}$ at $25^{\circ} \mathrm{C}$, and then centrifuged at $1400 \mathrm{xg}$ for 10 minutes. Serum aliquot was taken with assist of a micropipette and stored at $-20^{\circ} \mathrm{C}$ until analysis. Sera of 3 fish from the same experimental unit were pooled for immunological analyses.

The blood collected with syringe containing anticoagulant was used to produce duplicates of blood extensions dyed with Giemsa/MayGrunwald (Rosenfeld 1947), for differential counting of leukocytes and total counting of thrombocytes and leukocytes. One aliquot was used to determine hematocrit (Goldenfarb et al. 1971) and the rest was stored in glass flasks on ice to quantify the total number of erythrocytes in a hemocytometer. Total number of thrombocytes and leukocytes were counted in blood extension by the indirect method described by Martins et al. (2004). One aliquot of serum was used to determine glycemic index in spectrophotometer (Biotécnica ${ }^{\circledR}$ kit).

Agglutination titers were done individually for each bacteria strain ( $A$. hydrophila, E. durans and $P$. aeroginosa) according to the method described by Yildirim et al. (2003). Bacteria were cultured and inactivated following the protocol described earlier for the vaccine production. The concentration of inactivated cells used in the test was of 0.8 in $550 \mathrm{~nm}$ wave length $\left(O D_{550 \mathrm{~nm}}\right)$. The test was done in U-bottom 96-well microplate where fish serum was diluted at 1:1 ratio in saline phosphate buffer solution (PBS; 0.2M monobasic phosphate, 0.2M dibasic phosphate, $0.11 \mathrm{M}$ sodium chloride, $\mathrm{pH} 7.4$ ) in the first well (50iL of PBS solution:50il serum), and serially diluted in factor 2 for the remaining wells until the $12^{\text {th }}$. Then, 50il of inactivated bacteria was added to each well. The microplate was incubated at $25^{\circ} \mathrm{C}$ for $18 \mathrm{~h}$ in a wet chamber. Agglutination was visually confirmed by the observation of a button on the bottom of the well. The agglutinating titer was considered as the reciprocal of the last dilution that presented agglutination.

The antimicrobial activity was done in a flat-bottom 96-well microplate adapted from Schleder et al. (2008 in publication). Fish serum was evaluated for its antimicrobial activity against the bacteria strains, individually, $A$. hydrophila, E. durans and $P$. aeroginosa from the polyvalent vaccine, and Escherichia coli, a standard bacteria for this type of analysis. The bacteria used for the production of the vaccine was cultured in $\mathrm{BHI}$ (Difco), and $E$. coli was cultured in Luria broth (LB) at $30^{\circ} \mathrm{C}$ for $24 \mathrm{~h}$, prepared at a concentration of 0.5 of Macfarland scale and diluted 100,000 times in Poor broth (PB).

Serum was filtered in 22- $\mu \mathrm{m}$ Millipore filter to eliminate any possible bacterial contamination, $100 \mu \mathrm{L}$ PB was added to each well and $100 \mu \mathrm{L}$ serum was added to the first well of the line. Then, a factor 2 dilution was done serially until the $12^{\text {th }}$ well. As positive control, $0.65 \%$ saline solution in PB was diluted equally to the serum. Finally, $15 \mu \mathrm{L}$ of bacteria was added to each well. The same procedures were done for the blank, but without adding bacteria. The microplate was incubated at $25^{\circ} \mathrm{C}$ for $24 \mathrm{~h}$ under orbital agitation and the growth of microorganisms was determined in $O D_{550 \mathrm{~nm}}$ microplate reader. The serum antimicrobial activity was the reciprocal of the last dilution with bactericidal or bacteriostatic activity.

Data were submitted to the Bartlett test and hematological parameters with no homogenicity in variance were $\ln (x+1)$ transformed prior to analysis of variance with parcels subdivided in time $(\alpha<0.05)$. Differences in means were detected by the Student Newman Keuls test (SNK), and agglutination and antimicrobial inhibition data were $\log _{2}(x+1)$ transformed prior to analysis.

\section{RESULTS AND DISCUSSION}

Hematological parameters have been considered as important indicators of fish health (Chen et al. 2004, Martins et al. 2004). Studies demonstrated that the reduction in the number of erythrocytes in the blood and in the hematocrit percentage may be signs of bacterial infection (McNulty et al. 2003, Benli \& Yildiz 2004, Shoemaker et al. 2006b). In this study, tilapia did not present significant difference on day 7 after vaccination in hematocrit value ( $p>0.05$ ), however, the number of erythrocytes was lower in fish vaccinated orally and by immersion bath $(p<0.05)$ (Table 1). Yet, these values were similar to those observed in tilapia with no stress stimulation in the study accomplished by Martins et al. (2004).

On day 21, both total erythrocyte count and hematocrit percentage were higher in vaccinated fish than in the nonvaccinated, and those from the immersion group presented the highest hematocrit value $(p<0.05)($ Table 1$)$. These results agree with those published by Irianto et al. 2003 who observed an increase in erythrocyte count in goldfish (Carassius auratus) 14 days after oral vaccination against Aeromonas hydrophila.

In addition to hemostasis, thrombocytes play an important role in the host defense mechanisms, demonstrated by their action in coagulation and inflammatory processes, and the phagocytic activity in infectious processes (Tavares-Dias 2003). In this study, the number of thrombocytes in the tilapia blood was different only in the fish vaccinated orally on day 21 , which may be explained by the fact that the natural course of bacterial infection is oral (Austin \& Austin 1993, Kwon et al. 2007) and, according to Kwon et al. (2007), oral immunization is a promising alternative against bacteriosis.

Increase in tilapia glycemia can be used as a stress factor, according to Martins et al. (2004). However, in this study, glucose was stable in all fish except in those submitted to immersion vaccination on day 7 ( $p>0.05)$ (Table 1). These indexes were similar to those found in other studies with healthy Nile tilapia (Martins et al. 2004, Okamura et al. 2007). 
Table 1. Mean and standard error of hematological parameters of non-vaccinated Nile tilapia; intraperitoneally vaccinated fish with $1.5 \mathrm{~mL}$ of a suspension of $2 \times 10^{8}$ formalin-inactivated bacteria- $\mathrm{mL}^{-1}$; oral administration twice a day of vaccine-added feed containing $2 \times 10^{7}$ formalin-inactivated bacteria- $\mathrm{g}^{-1}$ during 5 days; immersion vaccination in solution with $2 \times 10^{7}$ formalin-inactivated bacteria- $\mathrm{mL}^{-1}$, during 20 minutes; on days 7 and 21 post-vaccination

\begin{tabular}{|c|c|c|c|c|c|}
\hline Days after & Treatments & Hematocrit (\%) & Erythrocytes $\left(10^{6} \cdot \mu \mathrm{L}^{-1}\right)$ & Thrombocytes $\left(10^{3} \cdot \mu \mathrm{L}^{-1}\right)$ & Leucocytes $\left(10^{3} \cdot \mu \mathrm{L}^{-1}\right)$ \\
\hline \multirow{3}{*}{7 days } & Control & $25,92 \pm 1,54 a$ & $2,09 \pm 0,17 a$ & $39,21 \pm 4,13 a$ & $13,88 \pm 0,84 c$ \\
\hline & Intraperitoneal vaccine & $27,94 \pm 0,80 a$ & $2,03 \pm 0,09 a$ & $35,41 \pm 4,14 a$ & $28,57 \pm 3,95 a$ \\
\hline & Oral vaccine & $26,47 \pm 1,90 a$ & $1,60 \pm 0,07 b$ & $24,79 \pm 2,53 a$ & $18,60 \pm 1,43 b$ \\
\hline \multirow{5}{*}{21 days } & Immersion vaccine & $28,94 \pm 1,04 a$ & $1,63 \pm 0,12 b$ & $31,03 \pm 2,13 a$ & $23,54 \pm 1,59 b$ \\
\hline & Control & $20,30 \pm 1,29 c$ & $1,96 \pm 0,05 b$ & $31,11 \pm 2,91 b$ & $14,47 \pm 2,02 c$ \\
\hline & Intraperitoneal vaccine & $27,28 \pm 0,64 b$ & $2,37 \pm 0,29 a$ & $32,72 \pm 4,56 b$ & $34,46 \pm 3,23 a$ \\
\hline & Oral vaccine & $28,44 \pm 0,65 b$ & $2,41 \pm 0,24 a$ & $40,78 \pm 4,69 a$ & $32,90 \pm 1,82 a$ \\
\hline & Immersion vaccine & $35,28 \pm 1,93 a$ & $2,41 \pm 0,14 a$ & $35,91 \pm 0,42 b$ & $22,45 \pm 1,30 b$ \\
\hline $\begin{array}{c}\text { Days after } \\
\text { vaccination }\end{array}$ & Treatments & $\begin{array}{c}\text { Neutrophilis } \\
\left(10^{3} \cdot \mu \mathrm{L}^{-1}\right)\end{array}$ & $\begin{array}{l}\text { Lymphocytes } \\
\left(10^{3} \cdot \mu \mathrm{L}^{-1}\right)\end{array}$ & $\begin{array}{l}\text { Monocytes } \\
\left(10^{3} \cdot \mu L^{-1}\right)\end{array}$ & $\begin{array}{l}\text { Glucose } \\
\left(\mathrm{mg} \cdot \mathrm{dL}^{-1}\right)\end{array}$ \\
\hline \multirow{3}{*}{ 7days } & Control & $5,01 \pm 1,25 b$ & $8,06 \pm 0,73 b$ & $0,78 \pm 0,06 c$ & $73,03 \pm 11,99 a$ \\
\hline & Intraperitoneal vaccine & $11,14 \pm 1,60 a$ & $14,32 \pm 1,84 a$ & $2,90 \pm 0,69 a$ & $85,72 \pm 11,13 a$ \\
\hline & Oral vaccine & $7,73 \pm 2,80 a b$ & $9,86 \pm 1,23 b$ & $0,98 \pm 0,18 b c$ & $77,39 \pm 7,46 a$ \\
\hline \multirow{5}{*}{21 days } & Immersion vaccine & $11,52 \pm 0,87 a$ & $10,62 \pm 0,84 b$ & $1,38 \pm 0,25 b$ & $47,27 \pm 11,27 b$ \\
\hline & Control & $4,99 \pm 1,03 b$ & $8,51 \pm 0,68 c$ & $0,97 \pm 0,35 b$ & $42,87 \pm 15,83 a$ \\
\hline & Intraperitoneal vaccine & $10,43 \pm 0,16 a$ & $22,91 \pm 3,01 a$ & $1,12 \pm 0,10 b$ & $40,06 \pm 13,11 a$ \\
\hline & Oral vaccine & $11,88 \pm 1,43 a$ & $19,29 \pm 2,98 a$ & $1,73 \pm 0,25 a$ & $55,70 \pm 12,53 a$ \\
\hline & Immersion vaccine & $8,44 \pm 0,66 a$ & $12,71 \pm 1,96 b$ & $1,26 \pm 0,11 b$ & $48,12 \pm 20,86 a$ \\
\hline
\end{tabular}

Different letters indicate significant differences by the SNK means comparison test $(p<0.05)$.

Several types of leukocytes participate in the cellular response, including lymphocytes, monocytes, granulocytes (neutrophils, eosinophils and basophils), and cytotoxic cells (Fernandez et al. 2002). On day 7, leukocyte and lymphocyte counts were higher in fish vaccinated by intraperitoneal injection, followed by oral administration and immersion bath vaccinations. On day 21 the same counts were increased in the blood of fish treated orally, similar to the intraperitoneal injection group ( $p>0.05)$. The nonvaccinated fish group presented leukocyte and lymphocyte counts lower $(p<0.05)$ than the vaccinated groups (Table 1$)$.

Neutrophil counts of fish vaccinated with intraperitoneal injection and immersion bath were higher on days 7 and 21 , whereas the oral administration group were significantly higher than the non-vaccinated fish $(p<0.05)$ only on day 21. Number of monocytes in the blood was higher on day 7 in fish vaccinated intraperitoneally, and on day 21 in fish vaccinated orally (Table 1 ). Basophils, eosinophils, and special granulocytic cells were found in very small proportions, so they were not analyzed.

Increase in the total leukocyte count in vaccinated tilapia found in this study was also observed in sturgeon and rainbow trout intraperitoneally vaccinated against $A$. hydrophila and three pathogenic species for the trout, respectively (Khoshbavar-Rostami et al. 2007, Nikoskelainen et al. 2007). In the study by Selvaraj et al. (2004), carp (Cyprinus carpio) immunized with LPS of $A$. hydrophila and in the study by Selvaraj et al. (2006) carp immunized with â-glucano plus LPS of $A$. hydrophila presented higher total leukocytes counts, in neutrophil and monocyte numbers but the number of lymphocytes remained constant.

Serum agglutination titer of fish vaccinated intraperitoneally was significantly higher $(p<0.05)$ in days 7 and
21 for the three bacteria strains used in this test. The serum of fish vaccinated by immersion bath or administration oral presented higher agglutination titer than the serum of fish non-vaccinated against $A$. hydrophila and lower than of those vaccinated intraperitoneally. The agglutination titer of Enterococcus durans was higher in fish of the justmentioned treatments than in the non-vaccinated and equal to the intraperitoneally vaccinated group only on day 21 $(\mathrm{p}<0.05)$ (Table 2).

Many studies report the increase in agglutination titer after fishes are vaccinated. In a previous work Nile tilapia presented higher agglutination after intraperitoneal vaccination against $S$. iniae (Klesius et al. 2000), and good indexes after challenged with $S$. iniae, only reducing on the tenth week post-infection (Shoemaker et al. 2006b). In a study by Selvaraj et al. (2004) carp immunized with LPS of $A$. hydrophila also presented high agglutination titer, as well as sturgeons intraperitoneally vaccinated against A. hydrophila that demonstrated good indexes until 29 days post-vaccination (Khoshbavar-Rostami et al. 2007).

The differences between agglutination titer for the different bacteria strains of the polyvalent vaccine of this study demonstrated that this analysis obtained specific responses for each strain and a positive correlation ( $r=0.74)$ between the number of lymphocytes and agglutination, suggesting that the antibodies played an important role in the agglutination of bacteria. Swain et al. (2007) reported that the Indian carp (Labeo rohita), after the administration of a polyvalent vaccine, presented higher agglutination titer, but with different indexes for each bacteria, as obtained in this study.

Monocytes also connect the non-specific with the specific immune system by producing cytokines that take 
Table 2. Agglutination titers $\left(\log _{2}(x+1)\right)$ and antimicrobial activity $\left(\log _{2}(x+1)\right)$ of non-vaccinated Nile tilapia serum; vaccinated by intraperitoneal injection of $1.5 \mathrm{~mL}$ of a suspension containing $2 \times 10^{8}$ formalin-inactivated bacteria- $\mathrm{mL}^{-1}$; by oral administration of vaccine-added feed with $2 \times 10^{7}$ formalin-inactivated bacteria- $\mathrm{g}^{-1}$, during 5 days; immersion bath vaccination in solution with $2 \times 10^{7}$ formalin-inactivated bacteria- $\mathrm{mL}^{-1}$, during 20 minutes; on days 7 and 21 post-vaccination

\begin{tabular}{|c|c|c|c|c|c|}
\hline \multirow{2}{*}{$\begin{array}{c}\text { Days after } \\
\text { vaccination }\end{array}$} & \multirow[t]{2}{*}{ Treatments } & \multicolumn{4}{|c|}{ Agglutination titre } \\
\hline & & A. hydrophila & P. aero & nosa & E. durans \\
\hline \multirow{3}{*}{7 days } & Control & $3,19 \pm 0,88 \mathrm{c}$ & \multicolumn{2}{|c|}{$0,53 \pm 0,92 b$} & $3,17 \pm 0,00 \mathrm{~b}$ \\
\hline & Intraperitoneal vaccine & $10,00 \pm 1,00 \mathrm{a}$ & \multirow{2}{*}{\multicolumn{2}{|c|}{$3,50 \pm 1,46$ a }} & $5,04 \pm 0,00 \mathrm{a}$ \\
\hline & Oral vaccine & $3,78 \pm 0,56 \mathrm{~b}$ & & $1,06 \pm 0,92 b$ & $2,89 \pm 0,49 b$ \\
\hline \multirow{5}{*}{21 days } & Immersion vaccine & $5,71 \pm 1,49 b$ & \multicolumn{2}{|c|}{$1,06 \pm 0,92 b$} & $2,89 \pm 0,49 b$ \\
\hline & Control & $2,75 \pm 0,60 \mathrm{c}$ & \multicolumn{2}{|c|}{$0,00 \pm 0,00 \mathrm{~b}$} & $2,75 \pm 0,60 b$ \\
\hline & Intraperitoneal vaccine & $10,33 \pm 0,58 a$ & \multicolumn{2}{|c|}{$4,43 \pm 1,46 a$} & $3,78 \pm 0,53 a$ \\
\hline & Oral vaccine & $5,70 \pm 0,56 \mathrm{~b}$ & \multicolumn{2}{|c|}{$0,00 \pm 0,00 \mathrm{~b}$} & $3,78 \pm 0,53 \mathrm{a}$ \\
\hline & Immersion vaccine & $6,04 \pm 1,96 \mathrm{~b}$ & \multicolumn{2}{|c|}{$0,00 \pm 0,00 \mathrm{~b}$} & $3,79 \pm 1,08 a$ \\
\hline \multirow{2}{*}{$\begin{array}{c}\text { Days after } \\
\text { vaccination }\end{array}$} & \multirow[t]{2}{*}{ Treatments } & \multicolumn{4}{|c|}{ Antimicrobial activity } \\
\hline & & A. hydrophila & $P$. aeroginosa & E. durans & E. coli \\
\hline \multirow{4}{*}{ 7days } & Control & $0,00 \pm 0,00 \mathrm{a}$ & $0,53 \pm 0,92 b$ & $0,00 \pm 0,00 \mathrm{a}$ & $1,06 \pm 0,92 b$ \\
\hline & Intraperitoneal vaccine & $0,00 \pm 0,00 \mathrm{a}$ & $8,34 \pm 1,15$ a & $0,00 \pm 0,00 \mathrm{a}$ & $7,36 \pm 2,84 \mathrm{a}$ \\
\hline & Oral vaccine & $0,00 \pm 0,00 \mathrm{a}$ & $6,70 \pm 2,47 a$ & $0,00 \pm 0,00 \mathrm{a}$ & $8,01 \pm 1,00 \mathrm{a}$ \\
\hline & Immersion vaccine & $0,00 \pm 0,00 \mathrm{a}$ & $7,35 \pm 2,06$ a & $0,00 \pm 0,00 \mathrm{a}$ & $7,68 \pm 1,15 a b$ \\
\hline \multirow{4}{*}{21 days } & Control & $0,00 \pm 0,00 \mathrm{a}$ & $3,48 \pm 0,53 b$ & $0,00 \pm 0,00 \mathrm{a}$ & $1,58 \pm 1,58 b$ \\
\hline & Intraperitoneal vaccine & $0,00 \pm 0,00 \mathrm{a}$ & $10,50 \pm 0,71 \mathrm{a}$ & $0,00 \pm 0,00 \mathrm{a}$ & $9,51 \pm 3,53$ a \\
\hline & Oral vaccine & $0,00 \pm 0,00 \mathrm{a}$ & $5,71 \pm 2,04 a$ & $0,00 \pm 0,00 \mathrm{a}$ & $7,51 \pm 2,11 \mathrm{a}$ \\
\hline & Immersion vaccine & $0,00 \pm 0,00 \mathrm{a}$ & $4,09 \pm 0,00 \mathrm{a}$ & $0,00 \pm 0,00 \mathrm{a}$ & $4,67 \pm 3,32$ a \\
\hline
\end{tabular}

Different letters indicate significant differences by the SNK means comparison test $(p<0.05)$.

the information to the lymphocytes, stimulating their activity (Ellis 1999). The higher number of monocytes on day 7 in intraperitoneally vaccinated fish and on day 14 in orally vaccinated fish may have contributed to the increase in the number of lymphocytes in these treatments in the respective days post-vaccination.

Fish serum from all treatments did no present antimicrobial activity against $A$. hydrophila and $E$. durans tested in this study. On the other hand, $P$. aeroginosa and E. coli had its growth inhibited by serum of fish vaccinated by the three routes on days 7 and 21 (Table 2). Yet, it is not clear which enzymes, proteins or other molecules have bactericidal activity or are responsible for such inhibition.

In this study, agglutination titer and serum antimicrobial activity results were different for each bacteria strain. Aeromonas hydrophila and $E$. durans were resistant to the antimicrobials but their agglutination titers were higher in vaccinated tilapia. Nevertheless, $P$. aeroginosa growth was inhibited by fish serum and low agglutination was seen only in fish vaccinated intraperitoneally. One hypothesis for this is that in fish vaccinated orally and by immersion bath there was a crossed reaction among the antigens, which inhibited the specific response against $P$. aeroginosa. This crossed reaction was observed in other studies with Atlantic salmon (Salmo salar) and rainbow trout, with $A$. salmonicida and $V$. salmonicida, and Listonella anguillarum and Flavobacterium psychrophilum, respectively (Hoel et al. 1997, Nikoskelainen et al. 2007).

Another hypothesis is that fish vaccinated orally and by immersion bath did not present good agglutination results for $P$. aeroginosa because they assimilated inefficient amounts of inactivated bacteria for adequate response. Ellis (1999) stated that antibodies recognize ironregulating proteins (IRP) of the external membrane and when such protein expresses little in the bacteria membrane, the antibody will need greater amount of bacteria to act.

Vaccines administrated by intraperitoneal injection have demonstrated good results in several studies, but alternatives that are more practical for large amounts of fish are required. Tilapia vaccinated by intraperitoneal injection against $S$. iniae presented higher relative survival rate, whereas results from oral and immersion bath vaccines were not satisfactory (Evans et al. 2004, Shoemaker et al. 2006a). However, the vaccine against $S$. iniae showed good results in a field study with Nile tilapia vaccinated twice by immersion bath before and after sexual reversion (Klesius et al. 2008). Senegalese sole (Solea senegalensis) and sea bass (Dicentrarchus labrax) also presented good protection with immersion bath only after a second vaccination (Arijo et al. 2005, Angelidis 2006).

Eels and turbot (Scophthalmus maximus) presented satisfactory results only after intraperitoneal vaccination, when compared to immersion bath vaccination (EsteveGassent et al. 2004, Santos et al. 2005), corroborating with the results of intraperitoneally vaccinated fish of this study. Nevertheless, oral and immersion routes also presented satisfactory results, similar or even higher in some parameters than the intraperitoneal route, especially on day 21.

Rainbow trout and Atlantic salmon presented higher stimulation of the immune system after the administration 
of a polyvalent vaccine, even better than the monovalent vaccines in the case of the salmon. Both studies reported different production of antibodies for the different bacteria strains (Hoel et al. 1997, Nikoskelainen et al. 2007). Nikoskelainen et al. (2007) recommended that bacterial antigens are to be chosen carefully for the polyvalent vaccine to avoid inhibitory effects of antigens in the fish specific response.

The polyvalent vaccine was efficient, vaccinated fish serum agglutinated $A$. hydrophila and $E$. durans, with antimicrobial activity against $P$. aeroginosa. The different administration routes stimulated hematological and immunological responses in Nile tilapia. The intraperitoneal injection presented the highest agglutination, but immersion bath and oral vaccines presented satisfactory results as well. The results also demonstrated that the different vaccine administration routes and the different antigens are stimulated at different moments for some parameters.

Acknowledgements.- The authors are thankful to 25 de Julho Foundation and to Roberto Hoppe, M.Sc. for providing the fish for the experiment; to CNPq for granting a Scientific Initiation scholarship to Bruno C. Silva, Research Productivity grant to Maurício L. Martins (CNPq301072/2007-8), and for the financial support (CNPq 472968/ 2007-6). The authors are also especially grateful to Dr. Elpídio Beltrame for all the pleasant moments shared and the help and support given to the members of the Microbiology Department of the Marine Shrimp Laboratory/LCM-UFSC.

\section{REFERENCES}

Angelidis P. 2006. Immersion booster vaccination effect on sea bass (Dicentrarchus labrax L.) juveniles. J. Anim. Physiol. Anim. Nutr. 90:46-49.

Arijo S., Rico R., Chabrillon M., Díaz-Rosales P., Martínez-Manzanares E., Balebona M.C., Magariños B., Toranzo A.E. \& Moriñigo M.A. 2005. Effectiveness of a divalent vaccine for sole, Solea senegalensis (Kaup), against Vibrio harveyi and Photobacterium damselae subsp. piscicida. J. Fish Dis. 28:33-38.

Austin B. \& Austin D.B. 1993. Bacterial fish pathogens in farmed and wild fish. $2^{\text {nd }}$ ed. Ellis Horwood Ltd, Chichester, England. 364p.

Benli A.C.K. \& Yildiz H.Y. 2004. Blood parameters in Nile tilapia (Oreochromis niloticus L.) spontaneously infected with Edwardsiella tarda. Aquacult. Res. 35:1388-1390.

Boyd C.E. \& Massaut L. 1999. Risks associated with the use of chemicals in pond aquaculture, Aquaculture 20:13-132.

Cai W., Li S. \& Ma J. 2004. Diseases resistance of Nile tilapia (Oreochromis niloticus), blue tilapia (Oreochromis aureus) and their hybrid (female Nile tilapia male blue tilapia) to Aeromonas sobria. Aquaculture 229:79-87.

Chen C.Y., Wooster G.A. \& Bowser P.R. 2004. Comparative blood chemistry and histopathology of tilapia infected with Vibrio vulnificus or Streptococcus iniae or exposed to carbon tetrachloride, gentamicin, or copper sulphate. Aquaculture 239:421-443.

Cipriano R.C. 2001. Aeromonas hydrophila and motile aeromonad septicaemias of fish. Fish Disease Leaflet 68, U.S. Department of the Interior, Fish and Wildlife Service, Division of Fisheries Research, Washington, D.C.

Ellis A.E. 1999. Immunity to bacteria in fish. Fish Shellfish Immunol. 9:291-308.

Esteve-Gassent M.D., Fouz B. \& Amaro C. 2004. Efficacy of a bivalent vaccine against eel diseases caused by Vibrio vulnificus after its administration by four different routes. Fish Shellfish Immunol. 16:93105
Evans J.J., Klesius P.H. \& Shoemaker C.A. 2004. Efficacy of Streptococcus agalactiae (group B) vaccine in tilapia (Oreochromis niloticus) by intraperitoneal and bath immersion administration. Vaccine 22:3769-3773.

Fernandez A.B., De Blasi I. \& Ruiz I. 2002. El sistema inmune de los teleósteos (I): Células y órganos. Rev. AcuaTic 16.

Goldenfarb P.B., Bowyer F.P., Hall E. \& Brosius E. 1971. Reproductibility in the hematology laboratory: The microhematocrit determination. Am. J. Clin. Pathol. 56:35-39.

Hoel K., Salonius K. \& Lillehaug A. 1997. Vibrio antigens of polyvalent vaccines enhance the humoral immune response to Aeromonas salmonicida antigens in Atlantic salmon (Salmo salar L.). Fish Shellfish Immunol. 7:71-80.

Irianto A., Robertson P.A. \& Austin B. 2003. Oral administration of formalin-inactivated cells of Aeromonas hydrophila A3-51 controls infection by atypical $A$. salmonicida in goldfish, Carassius auratus (L.). J. Fish Dis. 26:117-120.

Kaattari S.L. \& Piganelli J.D. 1996. The specific immune system: humoral defense, p.207-243. In: Iwama G. \& Nakanishi T. (Eds), The Fish Immune System. Academic Press, San Diego.

Khoshbavar-Rostami H.A., Soltani M. \& Hassan H.M.D. 2007. Immune responses of great sturgeon Huso huso to Aeromonas hydrophila bacterin. J. Fish Biol. 70:1931-1938.

Klaenhammer T.D. \& Kullen M.J. 1999. Selection and design of probiotics. Int. J. Food Microbiol. 50:45-57.

Klesius P.H., Shoemaker C.A. \& Evans J.J. 1999. Efficacy of an inactivated Streptococcus iniae vaccine in tilapia (Oreochromis niloticus). Eur. Assoc. Fish Pathol. 19(1):1-3.

Klesius P.H., Shoemaker C.A. \& Evans J.J. 2000. Efficacy of single and combined Streptococcus iniae isolate vaccine administered by intraperitoneal and intramuscular routes in tilapia (Oreochromis niloticus). Aquaculture 188:237-246.

Klesius P.H., Shoemaker C.A. \& Evans J.J. 2008. Immersion vaccination of tilapia (Oreochromis niloticus) using a Streptococcus iniae vaccine. Aquaculture America Conference, February 9-12, 2008. Lake Buena Vista, Florida, p.183. (Resumo)

Kwon S.R., Lee E.H., Nam Y.K., Kim S.K. \& Kim K.H. 2007. Efficacy of oral immunization with Edwardsiella tarda ghosts against edwardsiellosis in olive flounder (Paralichthys olivaceus). Aquaculture 269:84-88.

Lim C. \& Webster C.D. 2006 Tilapia: Biology, culture and nutrition. An Imprint of the Haworth Press, New York. 678p.

Martins M.L., Pilarsky F., Onaka E.M., Nomura D.T., Fenerick J., Ribeiro K., Miyazaki D.M.Y., Castro M.P. \& Malheiros E.B. 2004. Hematologia e resposta inflamatória aguda em Oreochromis niloticus (Osteichthyes: Cichlidae) submetida aos estímulos único e consecutivo de estresse de captura. Bolm Inst. Pesca, São Paulo, 30:7180 .

McNulty S.T., Klesius P.H., Shoemaker C.A. \& Evans J.J. 2003. Hematological changes in Nile tilapia (Oreochromis niloticus) infected with Streptococcus iniae by nare inoculation. J. World Aquacult. Soc. 34:418-422.

Nikoskelainen S., Verho S., Jarvinen S., Madetoja J., Wiklund T. \& Lilius E. 2007. Multiple whole bacterial antigens in polyvalent vaccine may result in inhibition of specific responses in rainbow trout (Oncorhynchus mykiss). Fish Shellfish Immunol. 22:206-217.

Okamura D., Araújo F.G., Logato P.V.R., Murgas L.D.S., Freitas R.T.F. \& Araújo R.V. 2007. Efeito da vitamina C sobre o hematócrito e glicemia de alevinos de tilápia-do-nilo (Oreochromis niloticus) em transporte simulado. Arq. Bras. Med. Vet. Zootec. 59(4):883-888.

Plumb J.A.1997. Infectious diseases of tilapia, p.212-228. In: CostaPierce B.A. \& Rakocy J.E. (Eds), Tilapia Aquaculture in the Americas. Vol.1. World Aquaculture Society, Baton Rouge, Luisiana.

Rosenfeld G. 1947. Corante pancrômico para hematologia e citologia clínica. Nova combinação dos componentes do May-Grünwald e do 
Giemsa num só corante de emprego rápido. Mem. Inst. Butantan 20:329-334.

Ruangpan L., Kitao T. \& Yoshida Y. 1986. Protective efficacy of Aeromonas hydrophila vaccine in Nile tilapia. Vet. Immunol. Immunopathol. 12:345-360.

Santos Y., Garcia-Marquez S., Pereira P.G., Pazos F., Riaza A., Silva R., El Morabit A. \& Ubeira F.M. 2005. Efficacy of furunculosis vaccines in turbot, Scophthalmus maximus (L.): Evaluation of immersion, oral and injection delivery. J. Fish Dis. 28:165-172.

Schleder D.D., Kayser M., Sühnel S., Ferreira J.F., Rupp G.S. \& Barracco M.A. 2008.Evaluation of some hemato-immunological parameters during the reproductive cycle of the scallop Nodipecten nodosus in association with a carotenoid-enriched diet. Aquaculture, 280(1-4):256263.

Secombes C.J. 1996. The Nonspecific Immune System: Cellular Defenses, p.63-105. In: Iwama G. \& Nakanishi T. (Eds), The Fish Immune System. Academic Press, London.

Selvaraj V., Sampath K. \& Sekar V. 2004. Extraction and characterization of lipopolysaccharide from Aeromonas hydrophila and its effects on survival and hematology of the carp, Cyprinus carpio. Asian Fish. Sci. 17:163-173.

Selvaraj V., Sampath K. \& Sekar V. 2006. Adjuvant and immunostimulatory effects of b-glucan administration in combination with lipopolysaccharide enhances survival and some immune parameters in carp challenged with Aeromonas hydrophila. Vet. Immunol. Immunopathol. 114:15-24.

Shoemaker C.A. \& Klesius P.H. 1997. Streptococcal disease problems and control: A review, p. 671-680. In: Fitzsimmons K. (Ed.), Tilapia Aquaculture. Vol.2. Northeast Regional Agricultural Engineering Service, Ithaca, NY.
Shoemaker C.A., Vandenberg G.W., Desormeaux A., Klesius P.H. \& Evans J.J. 2006a. Efficacy of a Streptococcus iniae modified bacterin delivered using Oralject ${ }^{\mathrm{TM}}$ technology in Nile tilapia (Oreochromis niloticus). Aquaculture 255:151-156.

Shoemaker C.A., Lim C., Yildirim-Aksoy M., Welker T.L. \& Klesius P. 2006b. Growth response and acquired resistance of Nile tilapia, Oreochromis niloticus (L.) that survived Streptococcus iniae infection. Aquacult. Res. 37:1238-1245.

Swain P., Behura A., Dash S. \& Nayak S.K. 2007. Serum antibody response of Indian major carp, Labeo rohita to three species of pathogenic bacteria; Aeromonas hydrophila, Edwardsiella tarda and Pseudomonas fluorescens. Vet. Immunol. Immunopathol. 117:137-141.

Tavares-Dias M. 2003. Variáveis hematológicas de teleósteos brasileiros de importância zootécnica. 209p. Tese de Doutorado em Aqüicultura, Centro de Aqüicultura, Universidade Estadual Paulista, Jaboticabal.

Tizard I.R. 2002. Imunologia Veterinária: uma introdução. Roca, São Paulo. 532p.

Vandenberg G.W., Gaudreault C., Dallaire V. \& Munger G. 2003. A novel system for oral vaccination of salmonids against furunculosis. Proc. Aquaculture in America, Louisville, KY, USA.

Vandenberg G.W. 2004. Oral vaccines for finfish: Academic theory or commercial reality? Anim. Health Res. Rev. 52:301-304.

Yano T. 1996. The nonspecific immune system: Humoral defense, p.207243. In: Iwama G. \& Nakanishi T. (Eds), The Fish Immune System. Academic Press, San Diego.

Yildirim M., Lim C., Wan P. \& Klesius P.H. 2003. Growth performance and immune response of channel catfish (Ictalurus puctatus) fed diets containing graded levels of gossypol-acetic acid. Aquaculture 219:751768. 